\title{
THE EFFECT OF AN INFUSION OF HYPERONCOTIC ALBUMIN ON THE EXCRETION OF WATER AND SOLUTES ${ }^{1,2}$
}

\author{
By R. G. PETERSDORF ${ }^{3}$ AND L. G. WELT 4 \\ (From the Department of Internal Medicine, Yale University School of Medicine, \\ New Haven, Conn.)
}

(Submitted for publication August 28, 1952; accepted December 24, 1952)

\section{INTRODUCTION}

Although there is good evidence that the rates of excretion of water and solutes are altered in response to a change in plasma volume $(1-3)$, the specific stimuli and the precise mechanisms through which the kidney modifies the volume and composition of the urine are not well understood. A decrease in plasma volume due to dehydration or increased transudation is accompanied by an increase in the oncotic pressure of the plasma, and it has been suggested that this rise in oncotic pressure may be one of the functions of a decrease in plasma volume that promotes a compensatory alteration in renal function.

Several recent investigations $(4,5)$ have demonstrated that an increase in the concentration of albumin and, presumably, an increase in the colloid osmotic pressure of the plasma in normal subjects results in a decrease in the rates of excretion of salt and, less consistently, water. The present investigation was undertaken to collect further data on the question of whether or not an increase in plasma oncotic pressure serves as a stimulus to antidiuresis and to determine whether such an antidiuresis represents a primary effect on water or is a passive consequence of a change in the rate of tubular reabsorption of salt.

\section{EXPERIMENTAL PROCEDURE AND METHODS}

The subjects of these studies were seven healthy male medical students and two patients with diabetes insipidus.

1 This work was supported by Contract No. DA-49007-MD-116 issued by the Medical Research and Development Board, Office of the Surgeon General, United States Army.

2 The serum albumin used in these studies was supplied by the American Red Cross.

8 This article represents work done in fulfillment of the thesis requirement for the degree of Doctor of Medicine at the Yale University School of Medicine.

4 Present address: Department of Medicine, School of Medicine, University of North Carolina, Chapel Hill, North Carolina.
The origin of the diabetes insipidus appeared to be postencephalitic in F. S. and due to reticuloendotheliosis in J. V. Both had an inability to concentrate the urine although the volumes in J. V. were not tremendous which may have been related to a coexisting mild hypothyroidism. Patient F. S. had the typical response of diabetes insipidus to the Hickey-Hare test (6). This was not performed on subject J. V. It is, of course, impossible to state whether the diabetes insipidus was "complete" in either instance.

Food, water, and tobacco were withheld 12 to 14 hours prior to and throughout each experiment, except in the studies in which fluids were permitted until the start of the experiment. The normal subjects were recumbent throughout the study except for the brief intervals attending vóiding. Urines were collected through an indwelling catheter in the two patients with diabetes insipidus. The experiments started at about 8 a.m. and lasted 7 to 11 hours.

Infusions of 200 to $500 \mathrm{cc}$. of 25 per cent salt-poor purified human serum albumin were administered at a time when these subjects were in a steady state of physiological diabetes insipidus (7). This condition was achieved by the infusion of a 5 per cent solution of glucose in water in such a manner as to attain and maintain a positive balance of water of approximately 1 liter throughout the study. The infusion of the solution of glucose was administered initially through two needles in different veins of one forearm by the use of a $Y$ tube leading from the infusion bottle. One of these needles was eventually used for the infusion of the solution of albumin and obviated the necessity of a venipuncture at the time of its administration. This infusion was started when the rate of flow of urine had been constant for four consecutive periods of approximately 30 minutes each. The concentration of sodium in 25 per cent salt-poor human albu$\mathrm{min}$ is $155 \mathrm{mEq}$. per liter. To avoid an increase in the concentration of sodium in the serum due to the infusion of albumin, the rate of administration of the 5 per cent glucose in water was accelerated by $300 \mathrm{cc}$. per hour coincident with the administration of the albumin. The most rapid infusion of albumin in any of the normal subjects was $100 \mathrm{cc}$. in 15 minutes ( $400 \mathrm{cc}$. per hour) and it, therefore, seems unlikely that the concentration of sodium in the serum could have been increased significantly. The experiments were continued beyond the period of the infusion of albumin until the rate of flow of urine was returning to or had reached the levels that characterized the control periods. 
Among the normal subjects there were four studies in which the solution of albumin was administered slowly, and four in which its administration was rapid. Two normal subjects were studied during both a rapid and slow administration of the albumin. The effects of an infusion of albumin were also compared with the administration of $2.5 \mathrm{mU}$ of pitressin in one subject. In one study, the subject sustained an antidiuretic response following each of two allegedly painless venipunctures.

Blood was drawn under oil at the start of each study, before and soon after the administration of the albumin, and at the end of the experiment. The second specimen of blood was drawn after three consecutive constant periods of urine flow and was followed by a fourth period

TABLE I

The effects of hyperoncotic solutions of albumin on the concentrations of proteins and electrolytes in serum and on the plasma volume

\begin{tabular}{|c|c|c|c|c|c|c|c|c|c|c|c|c|c|c|}
\hline \multirow[b]{2}{*}{ Study } & \multirow[b]{2}{*}{ Blood } & \multirow[b]{2}{*}{ Time } & \multirow{2}{*}{$\begin{array}{l}\text { I-V } \\
\text { alb. }\end{array}$} & \multicolumn{6}{|c|}{ Concentration in serum } & \multirow[b]{2}{*}{ Hkt. } & \multirow[b]{2}{*}{ Hgb. } & \multirow{2}{*}{$\begin{array}{l}\text { Hgb./ } \\
\text { Hkt. }\end{array}$} & \multirow{2}{*}{$\begin{array}{l}\mathbf{P V}_{\mathbf{2}} / \\
\mathbf{P V}_{\mathbf{1}}\end{array}$} & \multirow{2}{*}{$\begin{array}{c}\underset{P}{\Delta} \mathbf{P V} \\
\text { per } \mathbf{g m} \\
\text { Alb. }\end{array}$} \\
\hline & & & & T.P. & Alb. & Glob. & $\mathrm{Na}$ & $\mathrm{Cl}$ & $\mathbf{K}$ & & & & & \\
\hline J. A. & $\begin{array}{l}\text { I } \\
\text { II } \\
\text { III } \\
\text { IV }\end{array}$ & $\begin{array}{l}\text { min. } \\
274 \\
384 \\
455\end{array}$ & sm. & $\begin{array}{l}7.00 \\
6.53 \\
7.45 \\
6.82\end{array}$ & $\begin{array}{c}\text { gm. \% } \\
4.11 \\
4.02 \\
4.87 \\
4.46\end{array}$ & $\begin{array}{l}2.89 \\
2.51 \\
2.58 \\
2.36\end{array}$ & $\begin{array}{l}143 \\
140 \\
136 \\
135\end{array}$ & $\begin{array}{c}m E_{q} / L . \\
103 \\
99 \\
96 \\
96\end{array}$ & $\begin{array}{l}3.9 \\
4.0 \\
3.1 \\
3.4\end{array}$ & $\begin{array}{l}43.2 \\
43.9 \\
38.4 \\
38.0\end{array}$ & $\begin{array}{l}\text { gm. \% } \\
14.5 \\
14.4 \\
12.0 \\
12.9\end{array}$ & $\begin{array}{l}33.6 \\
32.8 \\
31.4 \\
32.7\end{array}$ & $\begin{array}{c}\% \\
100 \\
132 \\
123\end{array}$ & 18.5 \\
\hline K. B. & $\begin{array}{l}\text { I } \\
\text { III } \\
\text { IV }\end{array}$ & $\begin{array}{l}181 \\
298 \\
448\end{array}$ & 50 & $\begin{array}{l}6.90 \\
6.20 \\
6.82 \\
6.82\end{array}$ & $\begin{array}{l}4.46 \\
3.98 \\
4.84 \\
4.89\end{array}$ & $\begin{array}{l}2.44 \\
2.22 \\
1.98 \\
1.93\end{array}$ & $\begin{array}{l}142 \\
136 \\
139 \\
138\end{array}$ & $\begin{array}{l}105 \\
101 \\
104 \\
105\end{array}$ & $\begin{array}{l}4.4 \\
4.0 \\
3.9 \\
3.7\end{array}$ & $\begin{array}{l}46.4 \\
44.4 \\
39.0 \\
39.7\end{array}$ & $\begin{array}{l}15.1 \\
14.3 \\
12.4 \\
13.1\end{array}$ & $\begin{array}{l}32.7 \\
32.2 \\
31.8 \\
33.0\end{array}$ & $\begin{array}{l}100 \\
126 \\
118\end{array}$ & 17.6 \\
\hline M. T. & $\begin{array}{l}\text { I } \\
\text { II } \\
\text { III } \\
\text { IV }\end{array}$ & $\begin{array}{l}189 \\
349 \\
412\end{array}$ & 100 & $\begin{array}{l}6.90 \\
6.12 \\
7.00 \\
6.82\end{array}$ & $\begin{array}{l}4.18 \\
3.90 \\
4.95 \\
4.71\end{array}$ & $\begin{array}{l}2.72 \\
2.22 \\
2.05 \\
2.11\end{array}$ & $\begin{array}{l}143 \\
139 \\
139 \\
138\end{array}$ & $\begin{array}{r}105 \\
101 \\
99 \\
98\end{array}$ & $\begin{array}{l}4.1 \\
4.0 \\
3.9 \\
3.7\end{array}$ & $\begin{array}{l}46.9 \\
44.0 \\
35.9 \\
38.3\end{array}$ & $\begin{array}{l}14.8 \\
13.8 \\
10.1 \\
12.1\end{array}$ & $\begin{array}{l}31.5 \\
31.8 \\
28.2 \\
31.6\end{array}$ & $\begin{array}{l}100 \\
156 \\
126\end{array}$ & 30.2 \\
\hline $\begin{array}{l}\text { 4. } \\
\text { H. W. }\end{array}$ & $\begin{array}{l}\text { I } \\
\text { II } \\
\text { III }\end{array}$ & $\begin{array}{l}262 \\
342\end{array}$ & 50 & $\begin{array}{l}6.82 \\
6.53 \\
6.82\end{array}$ & $\begin{array}{l}4.21 \\
3.90 \\
4.64\end{array}$ & $\begin{array}{l}2.61 \\
2.63 \\
2.18\end{array}$ & $\begin{array}{l}142 \\
138 \\
135\end{array}$ & $\begin{array}{r}100 \\
98 \\
94\end{array}$ & $\begin{array}{l}3.9 \\
3.7 \\
3.3\end{array}$ & $\begin{array}{l}45.6 \\
44.0 \\
38.4\end{array}$ & $\begin{array}{l}14.2 \\
14.0 \\
12.9\end{array}$ & $\begin{array}{l}31.6 \\
31.8 \\
33.6\end{array}$ & $\begin{array}{l}100 \\
119\end{array}$ & 16.2 \\
\hline$R^{5 .} \cdot$ & II & & & 6.82 & 4.35 & 2.47 & 140 & 105 & 4.3 & 46.2 & 13.6 & 29.5 & & \\
\hline & III & $\begin{array}{l}295 \\
420\end{array}$ & 65 & $\begin{array}{l}6.82 \\
6.86\end{array}$ & $\begin{array}{l}5.21 \\
4.98\end{array}$ & $\begin{array}{l}1.61 \\
1.88\end{array}$ & $\begin{array}{l}134 \\
133\end{array}$ & $\begin{array}{l}96 \\
97\end{array}$ & $\begin{array}{l}3.3 \\
4.0\end{array}$ & $\begin{array}{l}38.2 \\
39.2\end{array}$ & $\begin{array}{l}12.2 \\
12.3\end{array}$ & $\begin{array}{l}31.9 \\
31.4\end{array}$ & & \\
\hline J. & $\begin{array}{l}\text { I } \\
\text { II } \\
\text { III } \\
\text { IV }\end{array}$ & $\begin{array}{l}206 \\
416 \\
654\end{array}$ & 100 & $\begin{array}{l}7.00 \\
6.64 \\
7.30 \\
7.35\end{array}$ & $\begin{array}{l}3.86 \\
3.19 \\
5.12 \\
4.94\end{array}$ & $\begin{array}{l}3.14 \\
3.45 \\
2.28 \\
2.39\end{array}$ & $\begin{array}{l}143 \\
138 \\
137 \\
138\end{array}$ & $\begin{array}{r}102 \\
100 \\
96 \\
96\end{array}$ & $\begin{array}{l}3.7 \\
3.8 \\
3.5 \\
3.5\end{array}$ & $\begin{array}{l}42.0 \\
39.7 \\
34.1 \\
37.3\end{array}$ & $\begin{array}{r}12.5 \\
12.1 \\
9.4 \\
11.2\end{array}$ & $\begin{array}{l}29.7 \\
30.5 \\
27.6 \\
30.0\end{array}$ & $\begin{array}{l}100 \\
141 \\
112\end{array}$ & 13.7 \\
\hline $\begin{array}{l}7 . \\
\text { H. W. }\end{array}$ & $\begin{array}{l}\text { I } \\
\text { II } \\
\text { III } \\
\text { IV }\end{array}$ & $\begin{array}{l}157 \\
312 \\
444\end{array}$ & 50 & $\begin{array}{l}6.64 \\
5.90 \\
6.33 \\
6.42\end{array}$ & $\begin{array}{l}4.09 \\
3.67 \\
4.35 \\
4.22\end{array}$ & $\begin{array}{l}2.55 \\
2.23 \\
1.98 \\
2.20\end{array}$ & $\begin{array}{l}145 \\
138 \\
139 \\
136\end{array}$ & $\begin{array}{l}105 \\
102 \\
101 \\
100\end{array}$ & $\begin{array}{l}3.6 \\
3.6 \\
3.0 \\
2.9\end{array}$ & $\begin{array}{l}46.7 \\
38.5 \\
33.4 \\
37.4\end{array}$ & $\begin{array}{l}15.0 \\
12.2 \\
10.9 \\
12.9\end{array}$ & $\begin{array}{l}32.7 \\
31.7 \\
32.6 \\
34.4\end{array}$ & $\begin{array}{r}100 \\
121 \\
96\end{array}$ & 17.6 \\
\hline $\begin{array}{l}\text { 8. T. } \\
\text {. }\end{array}$ & $\begin{array}{l}\text { I } \\
\text { II } \\
\text { III } \\
\text { IV }\end{array}$ & $\begin{array}{l}318 \\
498 \\
551\end{array}$ & 100 & $\begin{array}{l}6.64 \\
6.53 \\
7.25 \\
7.10\end{array}$ & $\begin{array}{l}4.24 \\
3.99 \\
5.04 \\
5.20\end{array}$ & $\begin{array}{l}2.40 \\
2.54 \\
2.21 \\
1.90\end{array}$ & $\begin{array}{l}139 \\
137 \\
138 \\
137\end{array}$ & $\begin{array}{r}103 \\
100 \\
99 \\
102\end{array}$ & $\begin{array}{l}3.9 \\
3.9 \\
3.8 \\
3.9\end{array}$ & $\begin{array}{l}45.0 \\
42.5 \\
38.8\end{array}$ & $\begin{array}{l}13.7 \\
13.0 \\
12.0\end{array}$ & $\begin{array}{l}30.5 \\
30.6 \\
30.9\end{array}$ & $\begin{array}{l}100 \\
115\end{array}$ & 8.2 \\
\hline F. S.* & $\begin{array}{l}\text { I } \\
\text { II } \\
\text { III } \\
\text { IV }\end{array}$ & $\begin{array}{r}65 \\
165 \\
257\end{array}$ & 62.5 & $\begin{array}{l}7.45 \\
6.46 \\
7.05 \\
6.68\end{array}$ & $\begin{array}{l}4.98 \\
4.11 \\
4.94 \\
4.84\end{array}$ & $\begin{array}{l}2.47 \\
2.35 \\
2.11 \\
1.84\end{array}$ & $\begin{array}{l}141 \\
135 \\
136 \\
137\end{array}$ & $\begin{array}{r}102 \\
97 \\
97 \\
93\end{array}$ & $\begin{array}{l}5.5 \\
4.7 \\
4.3 \\
4.5\end{array}$ & $\begin{array}{l}46.5 \\
42.4 \\
37.6 \\
38.4\end{array}$ & $\begin{array}{l}14.3 \\
12.5 \\
11.1 \\
11.4\end{array}$ & $\begin{array}{l}30.8 \\
29.5 \\
29.5 \\
29.7\end{array}$ & $\begin{array}{l}100 \\
122 \\
117\end{array}$ & 19.2 \\
\hline $\begin{array}{l}\text { 10. } \\
\text { F. S.* }\end{array}$ & $\begin{array}{l}\text { I } \\
\text { II } \\
\text { III } \\
\text { IV }\end{array}$ & $\begin{array}{r}92 \\
237 \\
280\end{array}$ & 125 & $\begin{array}{l}7.05 \\
6.28 \\
7.25 \\
7.20\end{array}$ & $\begin{array}{l}4.46 \\
4.14 \\
5.18 \\
4.96\end{array}$ & $\begin{array}{l}2.59 \\
2.14 \\
2.07 \\
2.24\end{array}$ & $\begin{array}{l}138 \\
132 \\
130 \\
128\end{array}$ & $\begin{array}{r}100 \\
92 \\
88 \\
90\end{array}$ & $\begin{array}{l}4.7 \\
3.9 \\
3.6 \\
3.5\end{array}$ & $\begin{array}{l}44.1 \\
41.2 \\
32.2 \\
32.8\end{array}$ & $\begin{array}{r}13.0 \\
12.0 \\
9.7 \\
9.9\end{array}$ & $\begin{array}{l}29.5 \\
29.1 \\
30.2 \\
30.1\end{array}$ & $\begin{array}{l}100 \\
142 \\
138\end{array}$ & 18.1 \\
\hline $\begin{array}{l}11 . \\
\text { J. V.t }\end{array}$ & $\begin{array}{l}\text { I } \\
\text { II } \\
\text { III }\end{array}$ & $\begin{array}{l}131 \\
210\end{array}$ & 60 & $\begin{array}{l}7.16 \\
6.82 \\
7.65\end{array}$ & $\begin{array}{l}3.03 \\
2.84 \\
3.73\end{array}$ & $\begin{array}{l}4.13 \\
3.98 \\
3.92\end{array}$ & & $\begin{array}{l}106 \\
103 \\
102\end{array}$ & $\begin{array}{l}4.2 \\
4.2 \\
4.0\end{array}$ & & & & & \\
\hline
\end{tabular}


during which the rate of excretion of water was observed to make certain that the venipuncture itself did not induce an antidiuresis.

Many of the chemical methods and calculations have been described in previous publications from this department $(8,9,10)$. The concentration of albumin in serum was determined by biuret (11) after the salting out of globulins by the method of Milne (12) as modified by Wolfson, Cohn, Calvary, and Ichiba (13). Creatinine in the serum and urine was determined by the method of Hare (14). The urines were not treated with Lloyd's reagent. The concentration of urea in urine and serum was determined as described by Conway (15). Since urinary ammonia was not determined, urea nitrogen was assumed to be equal to 93 per cent of urea plus ammonia nitrogen.

The clearance of endogenous creatinine was used as an estimate of the rate of glomerular filtration. The change in plasma volume, $P V_{2} / P V_{1}$, was estimated from the formula :

$$
\frac{\mathrm{Hgb}_{1}}{\mathrm{Hgb_{2 }}} \times \frac{1-\mathrm{Hkt}_{2}}{1-\mathrm{Hkt}_{1}} \times 100 .
$$

For purposes of estimating the approximate increase in plasma volume in cubic centimeters per gram of infused albumin, the original plasma volume was assumed to be 5 per cent of the body weight.

\section{RESULTS}

In every instance the infusion of albumin resulted in an expansion of the plasma volume (Table I). The magnitude varied between 8.2 and 19.2 cc. per gram of administered albumin. The average expansion of $16.1 \mathrm{cc}$. per gram is comparable

TABLE IIA

The effects of infusions of 25 per cent albumin on clearances, concentrations and rates of excretion of solutes in the urine (normal subjects)

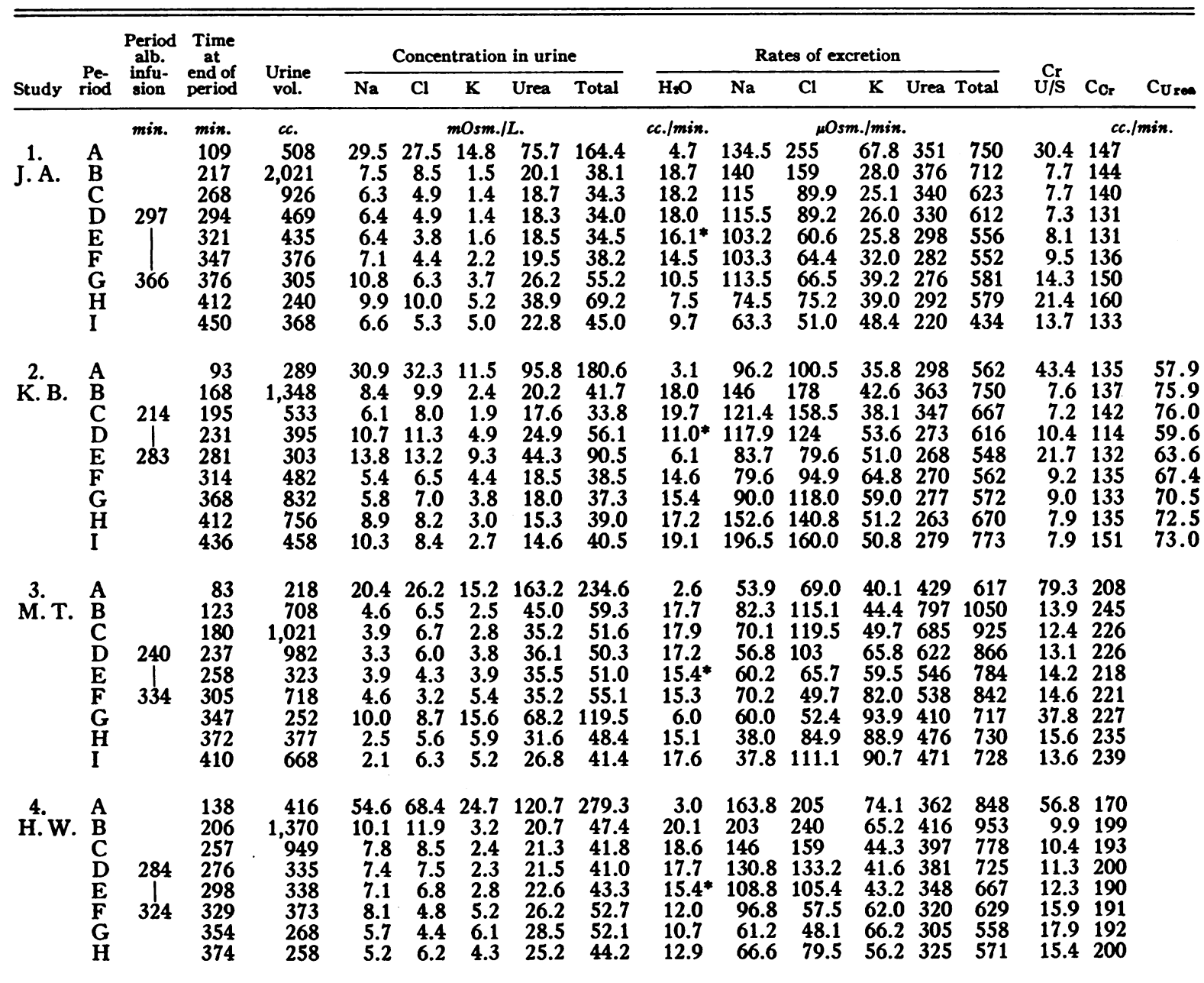


TABLE IIA-Continued

\begin{tabular}{|c|c|c|c|c|c|c|c|c|c|c|c|c|c|c|c|c|c|c|}
\hline \multirow[b]{2}{*}{ Study } & \multirow{2}{*}{$\underset{\text { riod }}{\text { Pe- }}$} & \multirow{2}{*}{$\begin{array}{l}\text { Period } \\
\text { abb. } \\
\text { infu- } \\
\text { sion }\end{array}$} & \multirow{2}{*}{$\begin{array}{l}\text { Time } \\
\text { att } \\
\text { end of } \\
\text { period }\end{array}$} & \multirow{2}{*}{$\begin{array}{l}\text { Urine } \\
\text { vol. }\end{array}$} & \multicolumn{5}{|c|}{ Concentration in urine } & \multicolumn{6}{|c|}{ Rates of excretion } & \multirow[b]{2}{*}{$\begin{array}{c}C_{\mathbf{C}} \\
\mathbf{U I S}\end{array}$} & \multirow[b]{2}{*}{$\mathrm{C}_{\mathbf{C r}}$} & \multirow[b]{2}{*}{ Curen } \\
\hline & & & & & $\mathbf{N a}$ & $\mathrm{Cl}$ & $\mathbf{K}$ & Urea & Total & $\mathrm{H}_{3} \mathrm{O}$ & $\mathrm{Na}$ & $\mathrm{Cl}$ & $\mathbf{K}$ & Urea & Total & & & \\
\hline $\begin{array}{l}\text { R. G. } \\
\text { R. }\end{array}$ & $\begin{array}{l}\text { A } \\
\text { B } \\
\text { C } \\
\text { D } \\
\text { E } \\
\text { F } \\
\text { G } \\
\text { H }\end{array}$ & $\begin{array}{c}218 \\
1 \\
282\end{array}$ & $\begin{array}{r}\text { min. } \\
90 \\
114 \\
139 \\
213 \\
238 \\
320 \\
371 \\
433\end{array}$ & $\begin{array}{r}c c . \\
155 \\
275 \\
341 \\
1,061 \\
302 \\
889 \\
652 \\
815\end{array}$ & $\begin{array}{r}35.7 \\
25.8 \\
8.6 \\
7.3 \\
6.7 \\
6.5 \\
7.7 \\
9.2\end{array}$ & $\begin{array}{r}58.0 \\
16.8 \\
9.9 \\
7.6 \\
7.9 \\
5.4 \\
4.0 \\
4.3\end{array}$ & $\begin{array}{c}m O s m . / 1 \\
31.3 \\
6.2 \\
4.0 \\
3.6 \\
4.1 \\
5.5 \\
2.9 \\
2.0\end{array}$ & $\begin{array}{r}158.8 \\
41.7 \\
29.7 \\
25.8 \\
26.4 \\
28.8 \\
23.6 \\
22.5\end{array}$ & $\begin{array}{r}292.8 \\
105.7 \\
55.0 \\
47.6 \\
48.2 \\
52.8 \\
44.9 \\
44.9\end{array}$ & $\begin{array}{c}c c . / \min . \\
1.7 \\
11.5 \\
13.8 \\
14.4 \\
12.1^{*} \\
10.9 \\
12.8 \\
13.2\end{array}$ & $\begin{array}{c} \\
64.1 \\
296 \\
119 \\
105 \\
81.5 \\
71.0 \\
98.4 \\
121\end{array}$ & $\begin{array}{r}\mu \mathrm{Os} \\
99.8 \\
192.2 \\
135.6 \\
109 \\
94.9 \\
58.5 \\
51.1 \\
56.8\end{array}$ & $\begin{array}{r}\text { m./min. } \\
53.8 \\
71.1 \\
54.1 \\
51.7 \\
50.1 \\
60.0 \\
37.6 \\
26.7\end{array}$ & $\begin{array}{l}273 \\
478 \\
403 \\
370 \\
316 \\
315 \\
301 \\
296\end{array}$ & $\begin{array}{r}504 \\
1212 \\
745 \\
683 \\
582 \\
576 \\
523 \\
590\end{array}$ & $\begin{array}{l}10.1 \\
10.6 \\
13.7 \\
11.4 \\
11.5\end{array}$ & $\begin{array}{l}143.0 \\
128 \\
149 \\
146 \\
151\end{array}$ & $\min$. \\
\hline $\begin{array}{c}6 . \\
J . L .\end{array}$ & $\begin{array}{l}\text { A } \\
\text { B } \\
\text { C } \\
\text { D } \\
\text { E } \\
\text { F } \\
\text { G } \\
\text { H } \\
\text { I }\end{array}$ & $\left.\right|_{408} ^{261}$ & $\begin{array}{r}91 \\
241 \\
255 \\
281 \\
381 \\
516 \\
544 \\
597 \\
650\end{array}$ & $\begin{array}{r}170 \\
1,726 \\
154 \\
263 \\
932 \\
1,154 \\
257 \\
525 \\
480\end{array}$ & $\begin{array}{r}14.0 \\
2.2 \\
2.0 \\
1.8 \\
1.5 \\
2.1 \\
2.7 \\
4.2 \\
5.3\end{array}$ & $\begin{array}{r}20.9 \\
3.2 \\
2.7 \\
2.0 \\
1.5 \\
1.2 \\
1.5 \\
1.4 \\
1.5\end{array}$ & $\begin{array}{r}10.2 \\
2.9 \\
4.2 \\
3.2 \\
7.2 \\
7.3 \\
4.6 \\
4.1 \\
4.2\end{array}$ & $\begin{array}{r}215.0 \\
49.0 \\
46.7 \\
47.1 \\
44.3 \\
41.1 \\
37.1 \\
32.0 \\
32.5\end{array}$ & $\begin{array}{r}263.4 \\
59.3 \\
59.3 \\
57.1 \\
61.7 \\
59.8 \\
51.7 \\
48.8 \\
51.7\end{array}$ & $\begin{array}{c}1.9 \\
11.5 \\
11.0 \\
10.1^{*} \\
9.3 \\
8.5 \\
9.2 \\
9.9 \\
9.1\end{array}$ & $\begin{array}{l}26.2 \\
25.6 \\
22.3 \\
17.9 \\
14.3 \\
17.7 \\
24.7 \\
42.1 \\
48.7\end{array}$ & $\begin{array}{l}39.1 \\
37.4 \\
30.2 \\
20.7 \\
14.3 \\
10.2 \\
14.2 \\
13.6 \\
14.0\end{array}$ & $\begin{array}{l}19.1 \\
33.8 \\
46.6 \\
32.7 \\
66.6 \\
62.7 \\
42.5 \\
41.1 \\
38.5\end{array}$ & $\begin{array}{l}402 \\
564 \\
514 \\
476 \\
412 \\
350 \\
341 \\
317 \\
296\end{array}$ & $\begin{array}{l}493 \\
682 \\
653 \\
577 \\
574 \\
509 \\
476 \\
483 \\
471\end{array}$ & $\begin{array}{l}87.6 \\
14.4 \\
15.8 \\
17.0 \\
19.8 \\
23.2 \\
21.2 \\
18.9 \\
20.0\end{array}$ & $\begin{array}{l}159 \\
166 \\
173 \\
142 \\
184 \\
197 \\
195 \\
187 \\
182\end{array}$ & \\
\hline $\begin{array}{l}7 . \\
\text { H. }\end{array}$ & $\begin{array}{l}\text { A } \\
\text { B } \\
\text { C } \\
\text { D } \\
\text { E } \\
\text { F } \\
\text { G } \\
\text { H } \\
\text { I }\end{array}$ & $\left.\right|_{303} ^{209}$ & $\begin{array}{r}90 \\
168 \\
206 \\
231 \\
281 \\
327 \\
365 \\
421 \\
440\end{array}$ & $\begin{array}{r}317 \\
1,357 \\
641 \\
375 \\
753 \\
355 \\
794 \\
845 \\
329\end{array}$ & $\begin{array}{r}39.6 \\
7.7 \\
6.5 \\
5.8 \\
5.5 \\
4.8 \\
5.6 \\
7.3 \\
8.3\end{array}$ & $\begin{array}{r}55.4 \\
9.4 \\
6.1 \\
4.8 \\
3.2 \\
3.9 \\
3.7 \\
4.6 \\
4.8\end{array}$ & $\begin{array}{r}24.1 \\
7.6 \\
6.0 \\
2.9 \\
3.4 \\
3.7 \\
3.1 \\
2.4 \\
1.9\end{array}$ & $\begin{array}{r}116.4 \\
24.8 \\
23.3 \\
24.1 \\
23.6 \\
24.3 \\
23.1 \\
19.8 \\
18.7\end{array}$ & $\begin{array}{r}243.8 \\
55.5 \\
48.4 \\
41.5 \\
41.4 \\
41.4 \\
40.5 \\
39.2 \\
39.1\end{array}$ & $\begin{array}{l}3.5 \\
17.4 \\
16.9 \\
15.0^{*} \\
15.0 \\
13.6 \\
13.6 \\
15.1 \\
17.3\end{array}$ & $\begin{array}{r}139.4 \\
134.2 \\
110.5 \\
86.8 \\
83.1 \\
65.5 \\
76.6 \\
109.7 \\
143.2\end{array}$ & $\begin{array}{r}196.5 \\
162.8 \\
103.4 \\
71.5 \\
48.5 \\
53.2 \\
50.1 \\
69.3 \\
82.5\end{array}$ & $\begin{array}{c}84.8 \\
133 \\
101.4 \\
44.0 \\
50.7 \\
50.7 \\
41.9 \\
36.5 \\
33.5\end{array}$ & $\begin{array}{l}597 \\
432 \\
394 \\
362 \\
354 \\
331 \\
314 \\
299 \\
327\end{array}$ & $\begin{array}{l}858 \\
966 \\
815 \\
623 \\
621 \\
563 \\
551 \\
592 \\
676\end{array}$ & $\begin{array}{l}50.2 \\
10.2 \\
10.5 \\
11.8 \\
12.0 \\
13.1 \\
13.3 \\
12.5 \\
12.2\end{array}$ & $\begin{array}{l}176 \\
177 \\
167 \\
178 \\
179 \\
178 \\
181 \\
189 \\
212\end{array}$ & \\
\hline $\begin{array}{l}\text { M. T. } \\
\text {. }\end{array}$ & $\begin{array}{l}\mathrm{A} \\
\mathrm{B} \\
\mathbf{C} \\
\mathrm{D} \\
\mathrm{E} \\
\mathbf{F} \\
\mathbf{G}\end{array}$ & $\left.\right|_{209} ^{69}$ & $\begin{array}{r}43 \\
66 \\
88 \\
134 \\
218 \\
255 \\
290\end{array}$ & $\begin{array}{r}747 \\
405 \\
373 \\
844 \\
1,630 \\
735 \\
817\end{array}$ & $\begin{array}{l}4.5 \\
4.3 \\
4.2 \\
4.9 \\
5.2 \\
5.2 \\
5.9\end{array}$ & $\begin{array}{l}7.2 \\
6.5 \\
6.5 \\
6.0 \\
6.0 \\
6.0 \\
7.2\end{array}$ & $\begin{array}{l}2.9 \\
2.7 \\
2.9 \\
3.5 \\
3.1 \\
3.4 \\
2.5\end{array}$ & $\begin{array}{l}24.9 \\
25.0 \\
24.3 \\
22.4 \\
19.3 \\
16.8 \\
14.9\end{array}$ & $\begin{array}{l}39.7 \\
39.0 \\
38.6 \\
39.1 \\
36.1 \\
34.1 \\
31.6\end{array}$ & $\begin{array}{l}17.4 \\
17.6 \\
17.0^{*} \\
18.3 \\
19.4 \\
19.9 \\
23.3\end{array}$ & $\begin{array}{r}78.7 \\
76.0 \\
73.3 \\
89.6 \\
101.4 \\
104.4 \\
136.5\end{array}$ & $\begin{array}{l}125.0 \\
114.4 \\
110.5 \\
109.6 \\
116.2 \\
119.1 \\
162.4\end{array}$ & $\begin{array}{l}50.5 \\
47.0 \\
48.7 \\
63.5 \\
61.1 \\
67.8 \\
58.0\end{array}$ & $\begin{array}{l}433 \\
440 \\
415 \\
410 \\
375 \\
334 \\
336\end{array}$ & $\begin{array}{l}691 \\
687 \\
657 \\
715 \\
700 \\
678 \\
736\end{array}$ & $\begin{array}{l}13.2 \\
13.1 \\
13.4 \\
13.1 \\
12.1 \\
11.9 \\
10.8\end{array}$ & $\begin{array}{l}229 \\
231 \\
228 \\
239 \\
235 \\
236 \\
251\end{array}$ & \\
\hline
\end{tabular}

* First period after start of infusion of albumin.

to that observed in another investigation (5) and is close to the theoretical value of $18 \mathrm{cc}$. per gram (16). The concentration of albumin in serum increased in all cases, providing evidence of an increase in the oncotic pressure of the plasma even after time for equilibration had been permitted. The infusions of albumin had no significant effect on the size of the red blood cells as measured by $\mathrm{Hgb} / \mathrm{Hkt}$. The initial decrease in the concentrations of total proteins, albumin, sodium, and chloride in the serum is the result of dilution by the positive balance of water.

In all but one study (no. 8) the rate of urine flow decreased in response to the infusions of 25 per cent albumin (Tables IIA and IIB). Although it is recognized that the clearance of endogenous creatinine may not be a precise measure of the rate of filtration at the glomerulus, the clearance of this substance in these studies would suggest that the changes in urine flow were unrelated to alterations in filtration rate except in study No. 9 in which the clearance of creatinine fell from 246 to $223 \mathrm{cc}$. per minute during the period of maximum antidiuresis. However, during the periods immediately preceding and following this, the clearance of creatinine did not decrease in spite of the fact that the rate of excretion of water was below the prealbumin infusion levels. Moreover, when this patient was studied a second time (no. 10), there was no change in the clearance of endogenous creatinine during the antidiuretic phase. In studies 2 and 5 there were transient decreases in the clearance of creatinine immediately following the start of the infusion of albumin. However, this decrease did not coincide with the maximum antidiuresis during which the clearance of creatinine had returned to the pre-albumin infusion levels.

The magnitude of the antidiuresis in normal 
TABLE IIB

The effects of infusions of 25 per cent albumin on clearances, concentrations, and rates of excretion of solutes in the urine (diabetes insipidus)

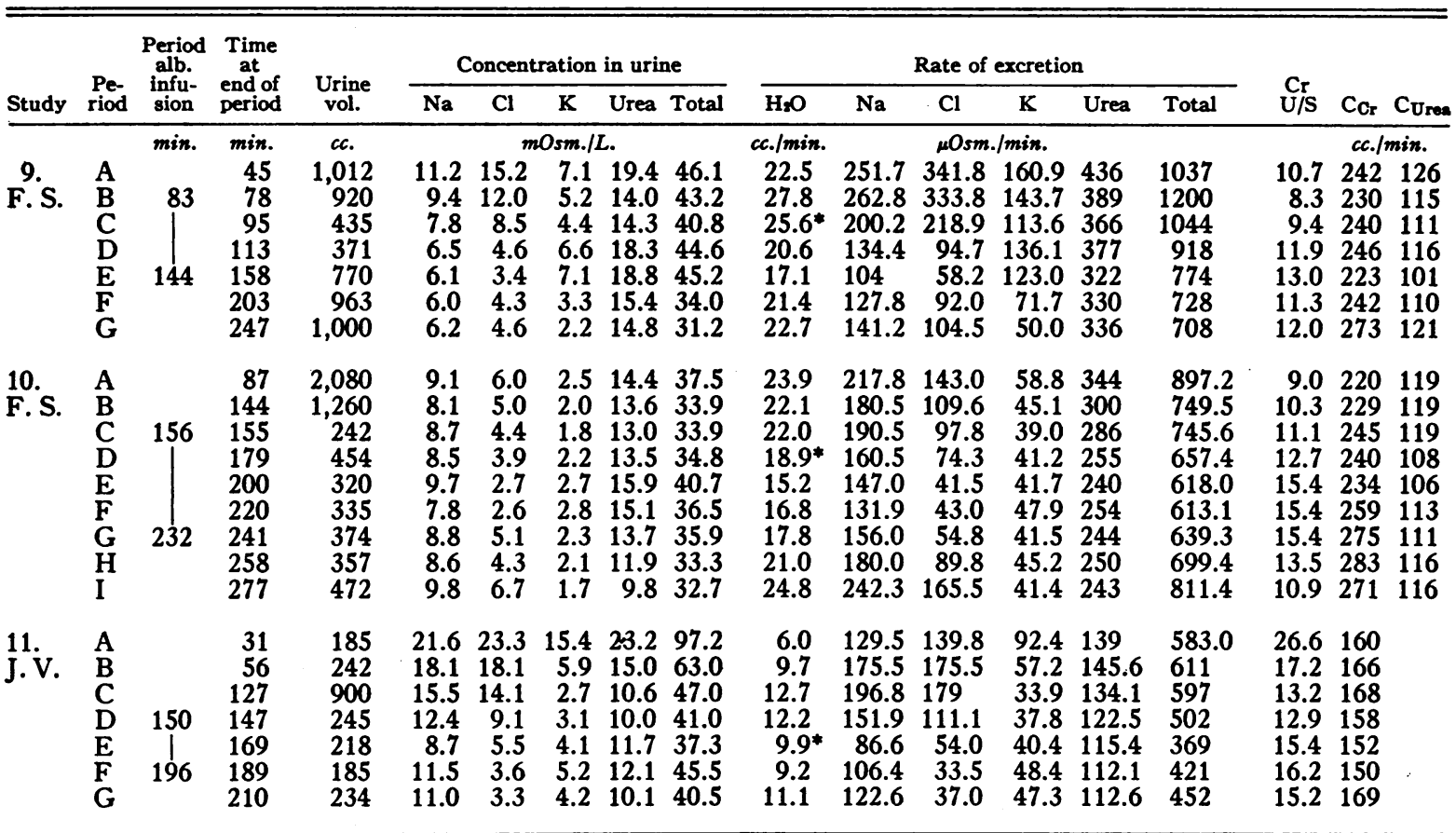

* First period after start of infusion of albumin.

subjects was invariably related to the rate at which the initial $25 \mathrm{gm}$. aliquot of albumin was administered (Tables III and IV). When the initial administration was rapid, the antidiuresis averaged 60 per cent (no. 1 to no. 4), whereas a slower infusion resulted in an average drop in urine flow

TABLE III

The effects of variations in the rate of administration of 25 per cent albumin on the magnitude and duration of antidiureses

\begin{tabular}{rcccc}
\hline \hline Study & $\begin{array}{c}\text { Amt. } \\
\text { alb. } \\
\text { infused }\end{array}$ & $\begin{array}{c}\text { Rate of } \\
\text { adm. of } \\
\text { first 25 } \\
\text { gm. alb. }\end{array}$ & $\begin{array}{c}\text { Rate of } \\
\text { adm. of } \\
\text { total } \\
\text { amt. alb. }\end{array}$ & $\begin{array}{c}\text { Max. } \\
\text { anti- } \\
\text { diuresis }\end{array}$ \\
\hline & gm. & gm./min. & gm./min. & $\%$ \\
1 & 60 & 1.66 & 0.86 & 58 \\
2 & 50 & 1.47 & 0.72 & 75 \\
3 & 100 & 1.56 & 1.06 & 65 \\
4 & 50 & 1.38 & 1.25 & 40 \\
5 & 65 & 0.78 & 1.01 & 24 \\
6 & 100 & 0.78 & 0.68 & 25 \\
7 & 50 & 0.69 & 0.53 & 17 \\
8 & 100 & 0.65 & 0.71 & $\begin{array}{c}\text { No anti- } \\
\text { diuresis }\end{array}$ \\
& & & & \\
9 & 62.5 & 1.25 & 1.02 & 33 \\
10 & 125 & 2.77 & 1.89 & 30 \\
11 & 60 & 2.08 & 1.30 & 38 \\
\hline
\end{tabular}

of 22 per cent in three studies (no. 5 to no. 7 ), and in a slight diuresis in study 8 . It is doubtful that variations in the rate of administration of the remainder of the infusion had any effect on the rate of excretion of urine. The validity of these observations was tested by administering identical amounts of albumin to the same subjects at rapid and slow rates on two different occasions (studies 4 and 7 , and 3 and 8 ). Their responses coincided with the pattern described above. The responses in the patients with diabetes insipidus were similar to those normal subjects to whom the albumin was administered slowly. The albumin was administered rapidly in each study of the patients with diabetes insipidus (no. 9 to no. 11) but the rate of excretion of urine diminished only 30 to 38 per cent.

The rate of excretion of total solutes was diminished during the periods of antidiuresis in all experiments except study 8 (Tables IIA and IV). These alterations were quite uniform and the delineation between slow and rapid infusions of albumin noted with respect to the excretion of water was not evident. 
R. G. PETERSDORF AND L. G. WELT

TABLE IV

The effect of infusions of 25 per cent albumin on the rates of excretion of $\mathrm{H}_{2} \mathrm{O}, \mathrm{Na}$, and total solutes

\begin{tabular}{|c|c|c|c|c|c|c|c|c|c|c|c|c|}
\hline \multirow[b]{2}{*}{ Study } & \multicolumn{3}{|c|}{$\begin{array}{l}\text { Rate of excretion } \\
\text { before albumin }\end{array}$} & \multicolumn{3}{|c|}{$\begin{array}{l}\text { Rate of excretion during } \\
\text { max. antidiuresis }\end{array}$} & \multicolumn{3}{|c|}{$\%$ decrease in rate } & \multirow[b]{2}{*}{$\frac{\% \Delta \mathrm{Na}}{\% \Delta \text { solutes }}$} & \multicolumn{2}{|c|}{$\mathrm{Cr} U / \mathrm{S}$} \\
\hline & $\mathrm{H}_{2} \mathrm{O}$ & $\mathbf{N a}$ & $\begin{array}{c}\text { Total } \\
\text { solutes }\end{array}$ & $\mathrm{H}_{2} \mathrm{O}$ & $\mathrm{Na}$ & $\begin{array}{l}\text { Total } \\
\text { solutes }\end{array}$ & $\mathrm{H}_{2} \mathrm{O}$ & $\mathrm{Na}$ & $\begin{array}{c}\text { Total } \\
\text { solutes }\end{array}$ & & $\begin{array}{l}\text { Before } \\
\text { alb. }\end{array}$ & $\begin{array}{c}\text { Max. } \\
\text { anti- } \\
\text { diuresis }\end{array}$ \\
\hline & cc./min. & \multicolumn{2}{|c|}{$\mu O s m . / m i n}$. & cc./min. & \multicolumn{2}{|c|}{$\mu O s m . / m i n}$. & & & & & & \\
\hline $\begin{array}{c}1 \\
2 \\
3 \\
4 \\
5 \\
6 \\
7 \\
8^{*} \\
9 \dagger \\
10 \dagger \\
11 \dagger\end{array}$ & $\begin{array}{l}18.0 \\
19.7 \\
17.2 \\
17.7 \\
14.4 \\
11.0 \\
16.9 \\
17.6 \\
25.6 \\
22.0 \\
12.6\end{array}$ & $\begin{array}{c}116 \\
121 \\
57 \\
131 \\
105 \\
22.3 \\
111 \\
76 \\
200 \\
191 \\
187\end{array}$ & $\begin{array}{r}612 \\
667 \\
866 \\
725 \\
683 \\
653 \\
815 \\
687 \\
1,044 \\
794 \\
576\end{array}$ & $\begin{array}{r}7.5 \\
6.1 \\
6.0 \\
10.7 \\
10.9 \\
8.5 \\
13.6 \\
19.9 \\
17.1 \\
15.2 \\
9.2\end{array}$ & $\begin{array}{l}75 \\
84 \\
38 \\
61.2 \\
69 \\
17.7 \\
66 \\
104.4 \\
104 \\
147 \\
106.4\end{array}$ & $\begin{array}{l}\mathbf{5 1 9} \\
548 \\
717 \\
\mathbf{5 5 8} \\
\mathbf{5 7 3} \\
\mathbf{5 0 9} \\
\mathbf{5 6 3} \\
\mathbf{6 7 8} \\
\mathbf{7 7 4} \\
\mathbf{6 1 8} \\
421\end{array}$ & $\begin{array}{r}58 \\
75 \\
65 \\
40 \\
24 \\
25 \\
17 \\
+12 \\
33 \\
30 \\
38\end{array}$ & $\begin{array}{r}35 \\
31 \\
33 \\
53 \\
34 \\
21 \\
41 \\
+32 \\
48 \\
23 \\
43.1\end{array}$ & $\begin{array}{c}15 \\
18 \\
17 \\
23 \\
16 \\
22 \\
31 \\
-\quad 2 \\
26 \\
22 \\
26.9\end{array}$ & $\begin{array}{l}2.33 \\
1.72 \\
1.94 \\
2.30 \\
2.12 \\
0.95 \\
1.32 \\
\\
1.84 \\
1.05 \\
1.60\end{array}$ & $\begin{array}{r}7.3 \\
7.2 \\
13.1 \\
11.3 \\
10.1 \\
15.8 \\
10.5 \\
13.1 \\
9.4 \\
11.1 \\
12.9\end{array}$ & $\begin{array}{l}21.4 \\
21.7 \\
37.8 \\
17.9 \\
13.7 \\
23.2 \\
13.3 \\
11.9 \\
13.0 \\
15.4 \\
16.2\end{array}$ \\
\hline
\end{tabular}

* Diuretic response.

$\uparrow$ Rapid infusions in patients with diabetes insipidus.

TABLE VA

The effects of $A D H$ on clearances, concentrations, and rates of excretion of solutes

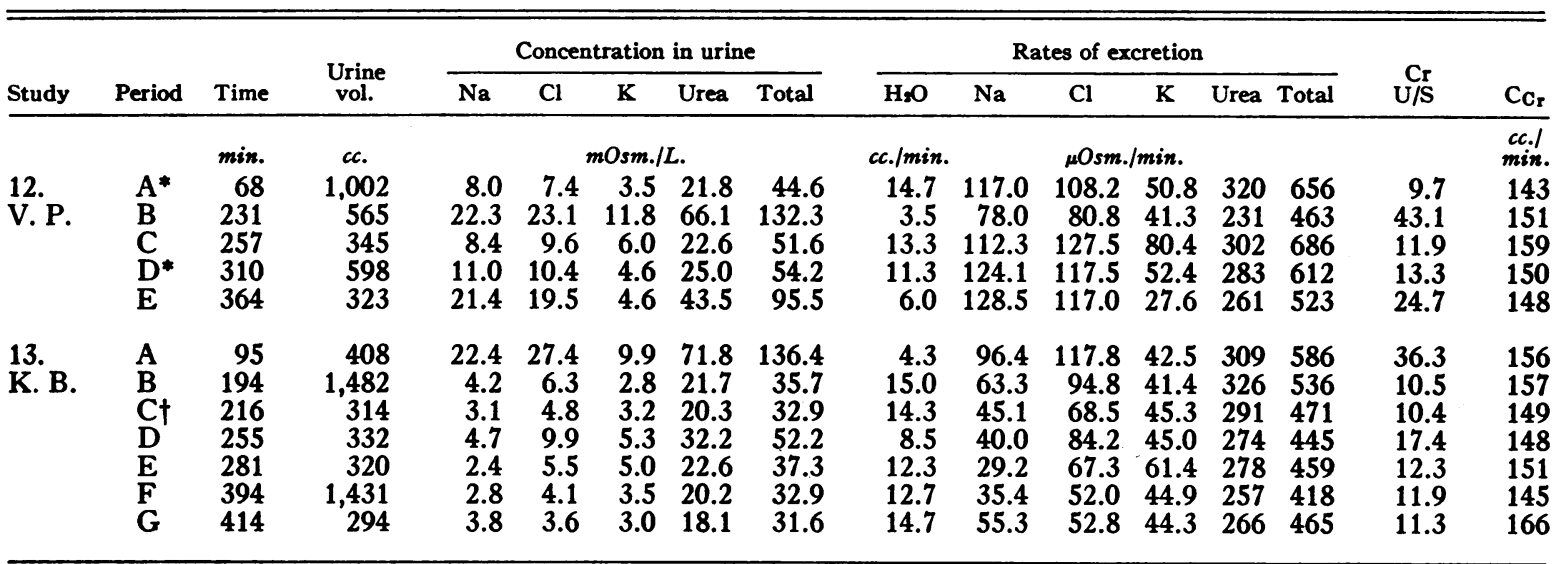

* Venipuncture.

$\uparrow 2.5 \mathrm{mU}$ pitressin I-V.

TABLE VB

The effects of endogenous and exogenous $\mathrm{ADH}$ on the rates of excretion of $\mathrm{H}_{2} \mathrm{O}, \mathrm{Na}$, and total solutes

\begin{tabular}{|c|c|c|c|c|c|c|c|c|c|c|c|c|}
\hline \multirow[b]{2}{*}{ Study } & \multicolumn{3}{|c|}{$\begin{array}{l}\text { Rate of excretion in } \\
\text { control period }\end{array}$} & \multicolumn{3}{|c|}{$\begin{array}{l}\text { Rate of excretion during } \\
\text { max. antidiuresis }\end{array}$} & \multicolumn{3}{|c|}{$\%$ decrease in rate } & \multirow[b]{2}{*}{$\frac{\% \Delta \mathrm{Na}}{\% \Delta \text { solutes }}$} & \multicolumn{2}{|c|}{$\mathrm{Cr} \mathrm{U} / \mathrm{S}$} \\
\hline & $\mathrm{H}_{2} \mathrm{O}$ & $\mathbf{N a}$ & $\begin{array}{c}\text { Total } \\
\text { solutes }\end{array}$ & $\mathrm{H}: \mathrm{O}$ & $\mathbf{N a}$ & $\begin{array}{c}\text { Total } \\
\text { solutes }\end{array}$ & $\mathrm{H}_{2} \mathrm{O}$ & $\mathbf{N a}$ & $\begin{array}{c}\text { Total } \\
\text { solutes }\end{array}$ & & $\begin{array}{c}\text { Control } \\
\text { period }\end{array}$ & $\underset{\text { Max. anti- }}{\text { diuresis }}$ \\
\hline & $c c . / \min$. & $\mu O s$ & n./min. & $c c . / m i n$. & $\mu O s s$ & . $/ \min$. & & & & & & \\
\hline $\begin{array}{l}12 * \\
13 t \\
\text { Ptt } \\
\text { Deltt } \\
\text { Stt } \\
\text { H } t \neq\end{array}$ & $\begin{array}{r}14.7 \\
11.3 \\
14.3 \\
14.4 \\
6.9 \\
14.8 \\
13.6\end{array}$ & $\begin{array}{r}117 \\
124 \\
45 \\
94 \\
160 \\
139 \\
73\end{array}$ & $\begin{array}{l}656 \\
612 \\
471\end{array}$ & $\begin{array}{l}3.5 \\
6.0 \\
8.5 \\
7.9 \\
2.7 \\
3.4 \\
4.7\end{array}$ & $\begin{array}{r}78 \\
128 \\
40 \\
104 \\
123 \\
86 \\
55\end{array}$ & $\begin{array}{l}463 \\
523 \\
445\end{array}$ & $\begin{array}{l}77 \\
47 \\
41 \\
45 \\
61 \\
77 \\
65\end{array}$ & $\begin{array}{r}33 \\
+\quad 4 \\
11 \\
+10 \\
23 \\
38 \\
25\end{array}$ & $\begin{array}{r}30 \\
14 \\
5\end{array}$ & $\begin{array}{l}1.1 \\
2.2\end{array}$ & $\begin{array}{r}9.7 \\
13.3 \\
10.4\end{array}$ & $\begin{array}{l}43.1 \\
24.7 \\
17.4\end{array}$ \\
\hline
\end{tabular}

* Venipuncture (probably endogenous ADH).

$+2.5 \mathrm{mU}$ pitressin administered I-V.

$\ddagger$ From: Nelson, W. P., III, and Welt, L. G., J.'Clin. Invest., 1952, 31, 392. 
The rate of excretion of sodium (and chloride) also diminished in all cases except no. 8. The magnitude of the antisaluresis was quantitatively similar in all studies. The alterations in the rate of excretion of sodium were relatively larger than those of total solutes as is demonstrated by examination of $\Delta \mathrm{Na} / \Delta$ solutes ratios presented in Table IV.

The rate of excretion of potassium was slightly accelerated during the antidiuretic phase in all cases. The rate of excretion of urea decreased in all studies during the antidiuresis. Although the rate of excretion of this solute remained low during the recovery periods in the face of a rising urine flow, the urea clearance returned to pre-albumin infusion levels during the recovery phase in those few instances in which it was measured (studies 2,9 , and 10).

One subject (no. 12) (Tables VA and VB) responded to two nontraumatic venipunctures with a marked inhibition in urine flow. Since this was not attended by a decrease in the clearance of creatinine, these antidiureses were presumed to be a consequence of the liberation of antidiuretic hormone by the posterior pituitary gland due to a non-specific emotional stimulus. The decrease in the rate of excretion of urine amounted to 77 and 47 per cent. In the first instance, the rate of excretion of total solutes as well as sodium diminished, but during the second antidiuresis the rate of excretion of total solutes diminished only slightly while that of sodium remained essentially unchanged.

In a final study, no. 13 (Tables VA and VB), an antidiuresis was produced by the intravenous administration of $2.5 \mathrm{mU}$ of pitressin. This was associated with only a small change in the rates of excretion of sodium or total solutes.

\section{DISCUSSION}

The antidiuresis promoted by the infusions of hyperoncotic solutions of albumin may be explained within the framework of the current concepts of renal physiology (17) as a consequence of a decrease in the rate of glomerular filtration or an increase in the renal tubular reabsorption of water. This latter, in turn, may occur as a passive consequence of an enhanced reabsorption of solutes, presumably in the proximal tubule, or as a result of the action of the antidiuretic hormone of the pos- terior pituitary gland, presumably in the distal portion of the nephron.

There is evidence from other studies $(4,5,18$, 19) employing the clearance of mannitol and inulin, as well as creatinine, that the infusion of a 25 per cent solution of albumin does not result in a decrease in the rate of glomerular filtration. The clearances of endogenous creatinine in this investigation would tend to support this contention. These antidiureses appear, therefore, to be dependent on an enhanced reabsorption of water in the renal tubules, and the increases in the creatinine $U / S$ ratios which accompanied the decreases in the rate of flow of urine support this thesis.

The importance of Verney's observations (20) concerning emotional stimuli as a factor in the liberation of $\mathrm{ADH}$ is vividly illustrated in study 12. This subject responded to two venipunctures with striking antidiureses. Since the venipuncture prior to the infusion of albumin did not cause an antidiuresis in studies 1 through 9 (see Experimental Procedure and Methods), and no further venipunctures were performed until after the antidiuresis had been observed, this type of trauma can be excluded as a cause for the decrease in urine flow observed in association with the infusions of albumin.

The antidiuresis promoted by the slow infusion of albumin was associated with a decrease in the rate of excretion of sodium, unaccompanied by an increase in the concentration of sodium or total solutes in the urine. The character of this antidiuresis was identical with that observed on three occasions in two patients with diabetes insipidus, and differed materially from that induced by a venipuncture and exogenous antidiuretic hormone. It appears unlikely, therefore, that the antidiuresis could have been mediated by a liberation of antidiuretic hormone from the posterior pituitary gland. Moreover, since the diminished rate of flow of urine was always associated with a decrease in the rate of excretion of solutes, it is most readily explained as an increased reabsorption of water secondary to increased solute reabsorption, presumably, in the proximal tubule.

The antidiuresis was more intense in those experiments on normal subjects in which the solution of albumin was administered rapidly. This is difficult to explain simply as a more profound expression of a single antidiuretic mechanism in re- 
sponse to a more intense stimulus for the following reasons:

1. The intensity of the antisaluresis was not influenced by the rate of infusion of the solution of albumin.

2. The rate of infusion of albumin in the patients with diabetes insipidus was comparable with the rapid infusions in the normal subjects, but the degree of antidiuresis in these patients was more comparable with that observed in the normals who received the albumin slowly.

These data imply that there may well have been an additional antidiuretic mechanism operating in the normal subjects who received the infusion of albumin at a rapid rate. The facts that this additional antidiuresis was unassociated with an additional antisaluresis, and was not elicited in the patients with diabetes insipidus, suggest that the rapid infusion of albumin may have stimulated the secretion of the antidiuretic hormone of the posterior pituitary gland.

Two sets of paired studies were performed in which the same subject was infused with the solution of albumin rapidly on one occasion and more slowly in another experiment. The role of a conditioned response was eliminated by reversing the order in which the paired studies were performed. In each instance the antidiuretic response was more marked with the rapid infusion of albumin. These studies would appear to eliminate an emotional reaction as the stimulus responsible for a posterior pituitary antidiuretic response associated with the rapid infusions.

Study 8 is anomalous and there is no obvious explanation for this discordant experiment. The fact that a diuresis occurred may be attributed to the increased rate of excretion of sodium.

It is not clear from these data whether solutes other than sodium and chloride are reabsorbed more rapidly when the oncotic pressure of the plasma is increased. The rate of excretion of potassium appeared to be accelerated. Urea was the only other osmotically active urinary solute determined. Since it presumably escapes from the glomerular filtrate by passive diffusion the excretion of urea may be expected to vary directly with urine flow. There is no information at this time concerning the effect of an increase in oncotic pressure of the plasma on the tubular reabsorption of glucose, bicarbonate, or other solutes.

The precise mechanism by which an increase in the rate of reabsorption of sodium occurs remains to be established. It has been suggested that the increase in colloid osmotic pressure of the plasma in the tubular vessels might serve to withdraw water and solutes out of the tubular lumen (21). This neglects the fact that the oncotic pressure of the plasma is effective in the transfer of fluid between the vascular compartment and the interstitial fluid and would not be expected to alter the distribution of fluid across the cell membrane. It has been previously suggested that there might be a receptor organ within the vascular tree that responded to alterations in oncotic pressure and, as a consequence of stimulation, promoted alterations in renal tubular activity with respect to the reabsorption of salt (5). It is clear that more data must be obtained before any explanation can be offered.

\section{SUMMARY AND CONCLUSIONS}

The intravenous administration of hyperoncotic solutions of albumin to normal subjects undergoing maximal diureses of water and to patients with diabetes insipidus results in an expansion of plasma volume. Since the increase in plasma volume exceeds the volume of the solution of albumin infused it is inferred that the oncotic pressure of the plasma had been increased and that this had promoted the movement of interstitial fluid into the blood stream. These changes were accompanied by decreased rates of excretion of solutes and water unassociated with a decrease in the rate of glomerular filtration.

The antidiureses observed in the normal subjects who received the infusions of albumin at a slow rate were qualitatively and quantitatively similar to the antidiureses observed in the patients with diabetes insipidus and, therefore, may be assumed to be independent of the antidiuretic hormone of the posterior pituitary gland. The increased renal tubular reabsorption of water appears to be best explained as a passive consequence of an enhanced reabsorption of sodium chloride, presumably in the proximal tubule.

The rapid administration of the solution of albumin increases the magnitude of the antidiuretic response in normal subjects, but not in patients 
with diabetes insipidus. In addition, the antidiuresis under these circumstances has some of the characteristics of a response to $\mathrm{ADH}$. It may be that a very rapid increase in oncotic pressure of the plasma promotes the secretion of $\mathrm{ADH}$ in addition to the acceleration of the tubular reabsorption of solutes.

\section{ACKNOWLEDGMENT}

The authors are indebted to Gloria E. Nassif, A.B., and Jane V. Lee, A.B., for their aid in these studies.

\section{REFERENCES}

1. Strauss, M. B., Davis, R. K., Rosenbaum, J. D., and Rossmeisl, E. C., Production of increased renal sodium excretion by hypotonic expansion of the extracellular fluid volume in recumbent subjects. J. Clin. Invest., 1952, 31, 80.

2. Lombardo, T. A., Eisenberg, S., Oliver, B. B., Viar, W. N., Eddleman, E. E., and Harrison, T. R., Effects of bleeding on electrolyte excretion and on glomerular filtration. Circulation, 1951, 3, 260.

3. Peters, J. P., Sodium, water and edema. J. Mt. Sinai Hosp., 1950, 17, 159.

4. Goodyer, A. V. N., Peterson, E. R., and Relman, A. S., Some effects of albumin infusions on renal function and electrolyte excretion in normal man. J. Applied Physiol., 1949, 1, 671.

5. Welt, L. G., and Orloff, J., The effects of an increase in plasma volume on the metabolism and excretion of water and electrolytes by normal subjects. J. Clin. Invest., 1951, 30, 751.

6. Hickey, R. C., and Hare, K., The renal excretion of chloride and water in diabetes insipidus. $\mathrm{J}$. Clin. Invest., 1944, 23, 768.

7. Verney, E. B., The antidiuretic hormone and the factors which determine its release. Proc. Roy. Soc., London, 1947, SB 135, 25.

8. Welt, L. G., and Nelson, W. P., III, Excretion of water by normal subjects. J. Applied Physiol., 1952, 4, 709.
9. Hald, P. M., The flame photometer for the measurement of sodium and potassium in biological materials. J. Biol. Chem., 1947, 167, 499.

10. Elkinton, J. R., and Taffel, M., Prolonged water deprivation in the dog. J. Clin. Invest., 1942, 21, 787.

11. Gornall, A. G., Bardawill, C. J., and David, M. M., Determination of serum proteins by means of the biuret reaction. J. Biol. Chem., 1949, 177, 751.

12. Milne, J., Serum protein fractionation: A comparison of sodium sulfate precipitation and electrophoresis. J. Biol. Chem., 1947, 169, 595.

13. Wolfson, W. Q., Cohn, C., Calvary, E., and Ichiba, F., Studies in serum proteins. V. A rapid procedure for the estimation of total protein, true albumin, total globulin, alpha globulin, beta globulin and gamma globulin in $1.0 \mathrm{ml}$. of serum. Am. J. Clin. Path., 1948, 18, 723.

14. Hare, R. S., and Hare, K., Endogenous creatinine in serum and urine. Proc. Soc. Exper. Biol. \& Med., 1950, 74, 148.

15. Conway, E. J., Microdiffusion Analysis and Volumetric Error. C. Lockwood, London, 1947, p. 357.

16. Scatchard, G., Batchelder, A. C., and Brown, A., Chemical, clinical and immunological studies on the products of human plasma fractionation. VI. The osmotic pressure of plasma and serum albumin. J. Clin. Invest., 1944, 23, 458.

17. Smith, H. W., The Kidney: Structure and Function in Health and Disease. Oxford Univ. Press, New York, 1951, pp. 241-352.

18. Cargill, W. H., Effect of intravenous administration of human serum albumin on renal function. Proc. Soc. Exper. Biol. \& Med., 1948, 68, 189.

19. Elkinton, J. R., Crosley, A. P., Jr., Barker, H. G., and Clark, J. K., Alterations in renal hemodynamics and excretion of electrolytes. Federation Proc., 1950, 9, 37.

20. Verney, E. B., Absorption and excretion of water. The antidiuretic hormone. Lancet, 1946, 2, 739.

21. Greiner, A., and Podhradszky, L., Kidney function in diabetes insipidus. Lancet, 1947, 2, 498. 